\title{
Talking Alcatraz
}

\section{A Chat with Gennifer Choldenko}

BY MOLLYY SENECHAL

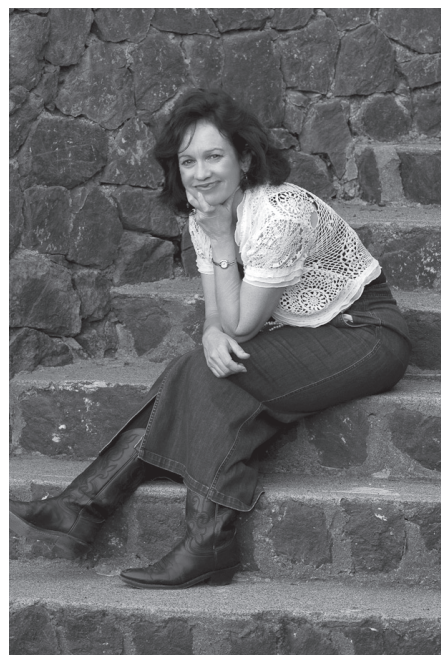

$\mathrm{G}$ ennifer Choldenko does not like to talk about herself. She does, however, like to talk about her books. And Alcatraz. And her local public library.

Late last year, I spoke with her by phone and delightfully discovered she is energetic, whip-smart, and very, very, funny. I want to drink coffee with her and chat for six hours. No, eight.

Choldenko is probably best known for her Al Capone trilogy, which tells the story of twelve-year-old Matthew "Moose" Flanagan and his family, who move to Alcatraz in 1935 so his sister Natalie, who is autistic, can attend a special school in San Francisco. The novels (Al Capone Does My Shirts, Al Capone Shines My Shoes, and Al Capone Does My Homework) are hilarious and touching in turns and center on the exploits of Moose, Natalie, and their friends, including the warden's danger-loving daughter. Money-making schemes, science experiments, and puppy love are all part of the picture.

Refreshingly, Moose, Natalie, and their friends do not remain stagnant through the series. Choldenko says she wanted her characters to progress and develop, to move forward from the place they left in the previous novel. It is Natalie who really shines in Al Capone Does My Homework, doing things Moose can't and coming into her own.

"I realized, when I was writing [Al Capone Does My Homework], that Natalie was old enough to do certain things," Choldenko said. "It was a surprise to me."

Before becoming a novelist, Choldenko worked as an advertising copywriter. After seven years in the industry she decided to change careers and go to art school. While she was sup- posed to be assembling her portfolio, she wrote her first novel. Choldenko says writing fiction is, in some ways, quite similar to writing advertising.

"Writing copy taught me to polish my words until they were the way I wanted them," she said. "It taught me to work on a deadline and work with a boss."

Polishing those (famous) words is sometimes done at the eleventh hour. Choldenko says she likes to try things out on the page and revise or remove them later if they don't quite fit - and sometimes, what doesn't fit is an entire chapter or two.

Writing Al Capone Does My Homework presented its own challenges.

"The problem I had writing it was that I had so many things I wanted to do," Choldenko said. "I had to give up some things because it was too much to put in one book." She also wanted the series to end on a high note because, she said, "You want to make the whole trilogy worth the readers' while."

Choldenko says she enjoys the process of writing as much as seeing the finished books. She admits to being a control freak, which

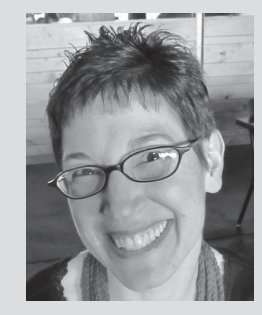

Molly Senechal is a news reporter-turnedlibrarian. She is a Children's Librarian at Brown County Library System in Green Bay, Wisconsin. 
can make releasing those books into the world a bit difficult.

"I get scared when I'm done and it's out of my hands," she said.

"I love writing books because the whole world is mine on the page. I try and let go once I'm finished. It's not my book any more ... it belongs to the readers."

I, for one, am glad of it. ¿

\section{Five Questions with Gennifer Choldenko}

\section{What is your favorite writing spot?}

I'm a rover. I have been known to write in my car, the library, the coffeehouse, and the car dealership. My favorite spot is my office, when my dog lets me have my chair.

\section{What are some of your writing rituals?}

I am a fanatic about very sharp Ticonderoga \#2 pencils. I carry seven of them all rubber banded together. I write on the computer, but edit fresh pages with sharp pencils. It is simply divine. Better than chocolate, even.

\section{What are some of your book tour rituals?}

I guess my one requirement for book tours is ridiculous amounts of caffeine. I also really love to work on a manuscript at the airport. In fact, that may be my favorite place to write.

4. What is your favorite section of the public library?

It changes depending on my mood. The nonfiction section is stimulating-I get a lot of ideas there. I also love the middle grade and young adult areas.

\section{What is your dream ice cream sundae?}

Chocolate, peanuts, banana, and peanut butter sauce. No ice cream. I hate ice cream.

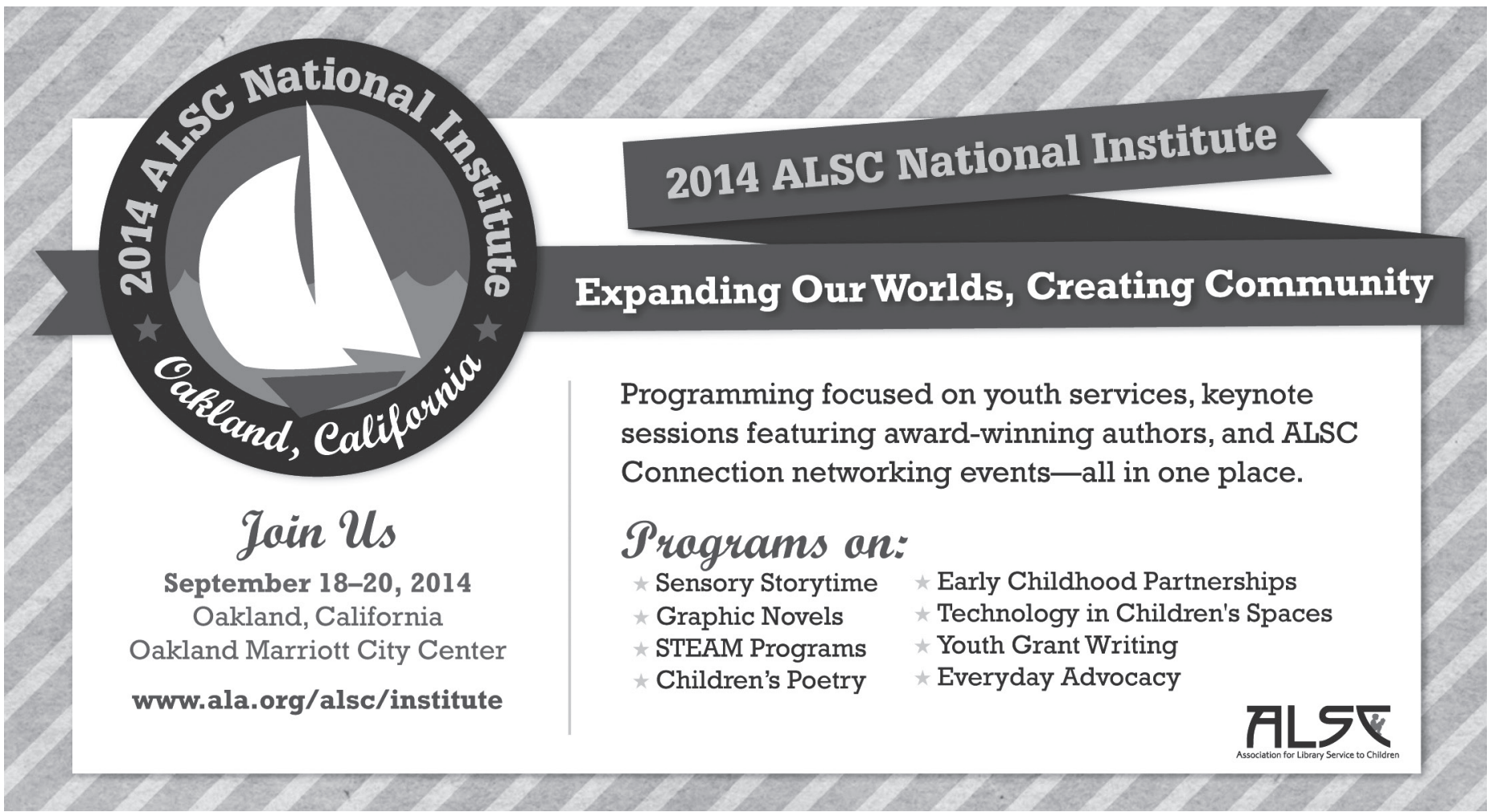

